\title{
Solar Ultraviolet Radiation and Climate Change Impact on Hill Stream Fishes of Himalayan Region India
}

\author{
Sunil Kumar ${ }^{1}$ and Rifhat Aara ${ }^{2}$
}

\begin{abstract}
Ozone depletion is resulting into elevation in solar ultraviolet-B radiation of 290-320 $\mathrm{nm}$. UV-B radiation and global warming pose threat to Himalayan ecosystem and biodiversity. Hill stream fishes, like Barilius and Nemachelius live in transparent surface water thus increases their chances of exposure to UVR still after photobleaching. Retene a natural chemical found in water become phototoxic with UV radiation. In this study, monitoring of solar UV-B was performed and effect of solar and elevated artificial UV-B was studied on fishes at high and low temperature with retene.

Growth, mortality, behaviour, lipid peroxidation, glutathione and catalase were performed. Solar UV-B shows seasonal, diurnal, altitudinal, latitudinal and annual variations with highest value in the month of July to September in Himalayan region India. Retene with UV radiation caused lipid peroxidation, decrease glutathione and generate reactive oxygen species. Barilius bendelisis was more sensitive than Nemachelius rupicola and showed higher mortality at high temperature. UV-B radiation and climate change lead to significant threat to Himalayan aquatic ecosystem.
\end{abstract}

Keywords-Biodiversity, Himalayan ecosystem, Solar Ultraviolet-B Radiation, Phototoxicity

\section{INTRODUCTION}

Solar UV undergoes significant absorption by the stratospheric ozone layer. With the depletion of the stratospheric ozone people and the environment will be exposed to higher intensities of UV. Extreme climatic condition in combination with anthropogenic contamination and increased solar UV-B may have a considerable impact on fresh water ecosystem [1]. Intensity of solar UV radiation and the depth of UV penetration into the water column are key factors in assessing the potential for damage to aquatic organisms [2]. The eggs and larvae of many fish are sensitive to UV-B exposure. Exposure to UV radiation whether of solar or artificial origin that is pointless in aquatic environments carried potentials risks to animals and plants, especially those inhabiting shallow water [3]. Due to the depletion of the ozone layer, biologically active solar UV-B radiation $(280-320 \mathrm{~nm})$ reaching the earth's surface has substantially increased over the past few decades and enhanced level of UV doses is

Sunil Kumar ${ }^{1}$ is with Toxicology lab, Department of Zoology, D.A.V. (P.G.) College Dehradun -248001 Affiliated to H. N. B. Garhwal Central University Srinagar, Uttarakhand - India.

Rifhat Aara ${ }^{2}$ is with Department of Zoology, D. A. V. (P.G.) College Dehradun -248001 as Research Scholar. predicted to continue [4]. The increase in UV radiation is associated with several adverse effects on human health, agriculture, animals, plants, and materials. The deleterious effect of UV-A and UV-B is enhanced and may become more toxic, when organisms are exposed to phototoxic chemicals. Climate change, phototoxic chemicals and UV-B can act as potential force for evolutionary changes, genetic diversity and function of ecosystem. Individual genetic sensitivity is also an important determinant of the susceptibility to UV radiation [5]. Such radiation may have negative effects on the aquatic ecosystem, resulting in decrease biomass productivity, including fish yield [6].

Cloud covers usually reduce the UV-B radiation by $20-50 \%$ in urban sites. Water reflects about $50 \%$ of the UV radiation and $60-80 \%$ is reflected from snow. At present concentration of the ozone depleting substance in the atmosphere are decreasing and according to recent models the stratospheric ozone is recovering [7], [8]. Polycyclic Aromatic hydrocarbons are present in the environment as complex mixtures, originating from petrogenic, biogenic, and pyrogenic sources. Natural sources of PAH include oil seeps, forest fires, and volcanoes, while anthropogenic inputs can include the burning of fossil fuels, production of coke and charcoal, metal smelting, petroleum refining, and petroleum spills. Retene (methyl isopropyl phenenthrene) is toxic for aquatic organisms including plants, invertebrates and vertebrates in presence of ultraviolet radiation [9].

Ultraviolet-B radiation negatively impacts organisms in both terrestrial and aquatic system. Within living cells, nucleic acids, proteins and lipids are the primary target of UV-B damage UV- B radiation acts synergistically with other stressors such as contaminants, disease and extremes thermal events [10]. Ultraviolet radiation is absorbed by biologically important molecules such as DNA, proteins, chromophores, which leads to wide ranging effects on organisms [11]. Studies in humans and laboratory animals have shown that lighter skinned individual are more sensitive to UVR than those with darken skin [12], [13]. Effect of UV radiation is affected by increase in temperature, climate change and response of organism regarding their protective strategies [14]. Studies on erythrocytes and Cyclops with photosensitizers were performed [15]. There is a lack of systematic and scientific knowledge on fish phototoxicity, enhanced solar ultraviolet radiation, photo sensitizers-toxicity and oxidative-stress with reference to current environmental conditions. Considering 
these perspectives an attempt has been made to assess the phototoxic potential of photosensitizer retene with change in temperature and intensity of ultraviolet-B radiation on hill stream fish Barillius bendelisis and Nemacheilus botia.

\section{Methodology}

Uttarakhand Himalayan region situated between latitude from $28^{\circ} 21^{\prime}$ to $30^{\circ} 21^{\prime}$ North latitude and $78^{\circ} 30^{\prime}$ to $80^{\circ} 30^{\prime}$ East longitude is selected for the monitoring purpose. Different sites were selected for monitoring of natural solar UV-B radiation and measured every month for four to six days on clear sunny days depending on the weather conditions using Cole- Parmer radiometer having Vilber Laurmat France calibrated UV-B sensor having spectral sensitivity $312 \mathrm{~nm}$. Data of different locations in relation to weather, season, altitude, latitude and monthly variation were collected. UV radiation was measured on clear sunny days at 12:00 \pm 20 noon at Dehradun $(600 \mathrm{msl})$, Mussoorie $(2000 \mathrm{msl})$ and Chamoli (3000 msl) in Uttarakhand India.

Fish larvae were collected and cultured by the method of Tisher and Songlake [16]. Larvae were divided into 8 groups with two replicates and two experimental protocols were designed. The first experimental setup was provided with temperature $20 \pm 2^{\circ} \mathrm{C}$. Group one kept as control, group two was exposed to retene, group three was given natural solar radiation, group four exposed to artificial UV-B, group five exposed to artificial UV-B of high intensity, group six exposed to solar radiation and retene, group seven exposed to artificial UV-B and retene and group eight exposed to artificial high intensity UV-B and retene. Second experimental setup having eight groups was prepared and was maintained at high temperature $30 \pm 2^{\circ} \mathrm{C}$. Solar radiation was given between 11:00 a.m. to 2:00 p.m., intensities for two hours per day. Solar radiation during experiment period in the month of September- October was of average intensity of 0.780 $\mathrm{mw} / \mathrm{cm}^{2}$. Artificial ultraviolet-B with same intensity and high intensity of $1.20 \mathrm{mw} / \mathrm{cm}^{2}$ was given by Philips UV-B lamps. Experiment was performed on fish Barilius bendelisis and Nemacheilus rupicola species available in hill streams of Uttarakhand, India.

Behavioral, morphological changes and mortality were recorded in fishes. Lipidperoxidation was assayed by measuring of malondialdehyde level in fish by using thiobarbiturc acid (TBA) through the method [17]. The absorbance was recorded using UV/ visible spectrophotometer at $532 \mathrm{~nm} .1,1,3$ tetramethoxy propane (Wako, Japan) was used as the standard. Reduced glutathione (GSH) was measured following the method [18] using dithiobis nitrobenzoic acid (DTNB). Absorbance was absorbed at 412 $\mathrm{nm}$ with the help of UV/ visible spectrophotometer. Catalase (E. C. 1. 1. 11. 6) $\mathrm{H}_{2} \mathrm{O}_{2}-\mathrm{H}_{2} \mathrm{O}_{2}$ oxidoreductase enzyme activity in the tissue was determined by breakdown of hydrogen peroxide using titration method [19]. Statistical inferences were drawn by using Students ' $t$ ' test [20].

\section{RESULTS AND DISCUSSION}

Natural solar UV-B radiation was lowest in January and February and maximum in July, August, September and October. Intensity of Solar UV-B radiation increases with increase in altitude. Result on monitoring of UV-B shows seasonal and altitudinal variations (Fig. 1). Results on mortality rate on fish indicate highest mortality in Barilius bendelisis with artificial UV-B and retene at high temperature. Intensity dependent species specific change in fish mortality was observed as mortality was low in Nemachelius than Barilius. Increase in temperature increase the mortality showing negative impact of temperature (Table 1, Fig. 2). Malondialdehyde level a marker of lipid peroxidation and cell injury indicated an increase in lipid peroxidation in comparison to control. Non- significant change was observed after exposure of individual retene and natural solar UV. However significant increase was observed after artificial UV radiation and UV radiation with combination of retene. MDA level was highest in Barilius bendelisis than Nemacheilus rupicola kept at high temperature and exposed to high intensity artificial UV-B with retene (Table 2). Glutathione level decreased in all the groups in comparison to control. Maximum decrease in GSH level was observed after high intensity of artificial UV-B + retene treated Barilius bendelisis fish followed by Nemacheilus rupicola (Table 3). Results on antioxidative enzyme catalase indicate decrease in antioxidant potential as level decreased in all the groups. Non- significant change was observed after retene and individual treatment of solar UV. Significant decrease in catalase was found after artificial UV-B and combination of retene with solar UV and artificial UV-B. Maximum reduction in enzyme level was observed in fish kept at high temperature (Table 4).

TABLE I

MORTALITY RATE AT DIFFERENT INTENSITIES OF SOLAR AND ARTIFICIAL UV RADIATION IN FISH BARILIUS BENDELISIS AND NEMACHEILUS RUPICOLA WITH RETENE AT LOW AND HIGH TEMPERATURE.

\begin{tabular}{llllll}
\hline \hline S. & \multicolumn{2}{c}{ Treatment } & \multicolumn{2}{c}{ Barilius bendelisis } & \multicolumn{2}{c}{ Nemacheilus rupicola } \\
No & & Low temp & \multicolumn{1}{c}{ High temp } & Low temp & High temp \\
\hline 1. & Control & $5 \pm 0.31^{\mathrm{NS}}$ & $6 \pm 0.5^{\mathrm{NS}}$ & $4.5 \pm 0.4^{\mathrm{NS}}$ & $5.0 \pm 0.31^{\mathrm{NS}}$ \\
2. & Retene & $5.5 \pm 0.33^{\mathrm{NS}}$ & $6.5 \pm 0.6^{\mathrm{NS}}$ & $5 \pm 0.4^{\mathrm{NS}}$ & $5.5 \pm 0.03^{\mathrm{NS}}$ \\
3. & Solar UV & $6.5 \pm 0.26^{\mathrm{NS}}$ & $7 \pm 0.8^{\mathrm{NS}}$ & $5.5 \pm 0.5^{\mathrm{NS}}$ & $6 \pm 0.45^{\mathrm{NS}}$ \\
4. & UV-B 1 & $7 \pm 0.86^{\mathrm{NS}}$ & $9 \pm 0.4^{*}$ & $6 \pm 1.02^{\mathrm{NS}}$ & $7 \pm 0.86^{\mathrm{NS}}$ \\
5. & UV-B 2 & $12 \pm 0.72^{*}$ & $14 \pm 0.7^{*}$ & $10 \pm 0.60^{*}$ & $11.5 \pm 0.71^{*}$ \\
6. & Solar + Retene & $21 \pm 1.05^{*}$ & $22 \pm 1.02^{*}$ & $18 \pm 1.05^{*}$ & $20 \pm 0.95^{*}$ \\
7. & UV-B1 + Retene & $24 \pm 0.9^{*}$ & $25 \pm 0.6^{*}$ & $22 \pm 0.7^{*}$ & $24 \pm 0.9^{*}$ \\
8. & UV-B2 + Retene & $26 \pm 0.95^{*}$ & $28 \pm 1.08^{*}$ & $23 \pm 1.1^{*}$ & $25 \pm 0.98^{*}$ \\
\hline \hline
\end{tabular}

Results are mean \pm S.E. of 5 observations in each group. P value * $0.05, \mathrm{NS}$ not significant 
TABLE II

EFFECT OF SOLAR AND ARTIFICIAL UV RADIATION ON LIPID PEROXIDATION (MALONDIALDEHYDE NANO MOLE/MG PROTEIN) IN FISH BARILIUS BENDELISIS AND NEMACHEILUS RUPICOLA WITH RETENE AT LOW AND HIGH TEMPERATURE.

\begin{tabular}{llllll}
\hline \hline S. & \multicolumn{1}{c}{ Treatment } & \multicolumn{2}{c}{ Barilius bendelisis } & \multicolumn{2}{c}{ Nemacheilus rupicola } \\
No & & \multicolumn{1}{c}{ Low temp } & \multicolumn{1}{c}{ High temp } & Low temp & High temp \\
\hline 1. & Control & $7.40 \pm 0.38$ & $7.45 \pm 0.42$ & $7.35 \pm 0.65$ & $7.40 \pm 0.38$ \\
2. & Retene & $8.03 \pm 0.62^{\mathrm{NS}}$ & $8.03 \pm 0.81^{\mathrm{NS}}$ & $7.40 \pm 0.72^{\mathrm{NS}}$ & $7.43 \pm 0.80^{\mathrm{NS}}$ \\
3. & Solar UV & $7.95 \pm 0.68^{\mathrm{NS}}$ & $8.05 \pm 0.63^{\mathrm{NS}}$ & $7.72 \pm 0.85^{\mathrm{NS}}$ & $7.95 \pm 0.65^{\mathrm{NS}}$ \\
4. & UV-B 1 & $8.12 \pm 0.80^{*}$ & $8.32 \pm 0.78^{*}$ & $8.02 \pm 0.70^{*}$ & $8.12 \pm 0.67^{*}$ \\
5. & UV-B 2 & $8.85 \pm 0.63^{*}$ & $9.15 \pm 0.84^{*}$ & $8.42 \pm 0.63^{*}$ & $8.45 \pm 0.63^{*}$ \\
6. & Solar + Retene & $9.01 \pm 0.45^{*}$ & $9.10 \pm 0.76^{*}$ & $8.31 \pm 0.72^{*}$ & $8.56 \pm 0.75^{*}$ \\
7. & UV-B1 + Retene & $9.25 \pm .92^{* *}$ & $10.05 \pm 0.62^{* *}$ & $9.05 \pm 0.78^{* *}$ & $9.55 \pm 0.92^{* *}$ \\
8. & UV-B2 + Retene & $10.18 \pm 0.73^{* *}$ & $10.95 \pm 0.86^{* *}$ & $9.70 \pm 0.91^{* *}$ & $10.26 \pm 0.84^{* *}$ \\
\hline \hline
\end{tabular}

Results are mean \pm S.E. of 5 observations in each group. P value $* 0.05$, *0.01, NS not significant.

TABLE III

EFFECT OF SOLAR AND ARTIFICIAL UV RADIATION ON REDUCED GLUTATHIONE LEVEL (MG/ G OF TISSUE) IN FISH BARILIUS BENDELISIS AND NEMACHEILUS RUPICOLA WITH RETENE AT LOW AND HIGH TEMPERATURE.

\begin{tabular}{|c|c|c|c|c|}
\hline \multirow{2}{*}{$\begin{array}{c}\text { S. } \\
\text { No. }\end{array}$} & \multirow[t]{2}{*}{ Treatment } & \multicolumn{2}{|c|}{ Barilius bendelisis } & Nemacheilus $r$ \\
\hline & & Low temp & High temp & Low temp High temp \\
\hline 1. & Control & $980 \pm 2.80$ & $980 \pm 2.80$ & $975 \pm$ \\
\hline ?. & & $962 \pm 3.31^{\mathrm{NS}}$ & $960 \pm 3.31^{\mathrm{NS}}$ & $950 \pm 2.01^{\mathrm{NS}} 941$ \\
\hline 3. & & $38 \pm 5.13^{*}$ & $928 \pm 5$. & $920 \pm 4.13^{*} 928$ \\
\hline 4. & UV-B 1 & $892 \pm 2.14^{*}$ & $865 \pm 2.14^{*}$ & $872 \pm 2.12^{*}$ \\
\hline 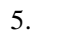 & UV-B 2 & $840 \pm 4$ & $832 \pm 4.02^{*}$ & $830 \pm 2.02^{*} \quad 829 \pm 3.01^{*}$ \\
\hline 6. & Solar + Retene & $798 \pm 1$ & $778 \pm 1.78^{* *}$ & $789 \pm 1.35^{* *} 776 \pm 1.58^{* *}$ \\
\hline 7. & UV-B1 + & $695 \pm 3.27^{* * *}$ & $685 \pm 3.27^{* *}$ & $.17^{* *} 707 \pm 2.26^{* *}$ \\
\hline & UV-B2 + Retene & $680 \pm 2.10^{* *}$ & $660 \pm 2.10^{* * *}$ & $697 \pm .1 .14^{* *} 675 \pm 1.11^{* *}$ \\
\hline
\end{tabular}

Results are mean \pm S.E. of 5 observations in each group. $\mathrm{P}$ value $* 0.05$, *0.01, NS not significant

TABLE IV

EFFECT OF SOLAR AND ARTIFICIAL UV RADIATION ON CATALASE IN FISH BARILIUS BENDELISIS AND NEMACHEILUS RUPICOLA WITH RETENE AT LOW AND HIGH TEMPERATURE.

\begin{tabular}{|c|c|c|c|c|c|}
\hline \multirow{2}{*}{$\begin{array}{l}\text { S. } \\
\text { No }\end{array}$} & \multirow[t]{2}{*}{ Treatment } & \multicolumn{2}{|c|}{ Barilius bendelisis } & \multicolumn{2}{|c|}{ Nemacheilus rupicola } \\
\hline & & Low temp & $\begin{array}{l}\text { High } \\
\text { temp }\end{array}$ & $\begin{array}{l}\text { Low } \\
\text { temp }\end{array}$ & $\begin{array}{l}\text { High } \\
\text { temp }\end{array}$ \\
\hline 1. & Control & $81.2 \pm 1.42$ & $80.5 \pm 1.42$ & $79.0 \pm 1.22$ & $78.0 \pm 1.42$ \\
\hline 2. & Retene & $79.3 \pm 1.84^{\mathrm{NS}}$ & $73.3 \pm 1.84^{\mathrm{NS}}$ & $75.1 \pm 1.64^{\mathrm{NS}}$ & $72.3 \pm 1.40^{*}$ \\
\hline 3. & Solar UV & $78.7 \pm 1.16^{\mathrm{NS}}$ & $78.7 \pm 1.16^{\mathrm{NS}}$ & $74.1 \pm 1.06^{\mathrm{NS}}$ & $76.7 \pm 1.06^{*}$ \\
\hline 4. & UV-B 1 & $74.2 \pm$ & $74.1 \pm 1.91 *$ & $71.2 \pm$ & $73.2 \pm 1.01^{*}$ \\
\hline 5. & UV-B 2 & $71.6 \pm 2$ & $76.6 \pm 2.16^{*}$ & $73.6 \pm 2.16^{*}$ & $74.6 \pm 2.16^{*}$ \\
\hline 6. & Solar + Retene & $70.7 \pm 1.75^{*}$ & $73.7 \pm 1.75^{*}$ & $71.7 \pm 1.75^{*}$ & $72.7 \pm 1.75^{*}$ \\
\hline 7. & UV-B1 t & $67.5 \pm 1.98 * *$ & $67.5 \pm 1.98 * *$ & $65.5 \pm 1.98^{*} *$ & $65.5 \pm 1.98 *$ \\
\hline 8. & UV-B2 + Retene & $62 \pm 1.97 * *$ & $58.6 \pm 1.97 * *$ & $62.8 \pm 1.97^{*} *$ & $61.2 \pm 1.97^{*}$ \\
\hline
\end{tabular}

Results are mean \pm S.E. of 5 observations in each group. $\mathrm{P}$ value $* 0.05$, $* 0.01$, NS not significant.

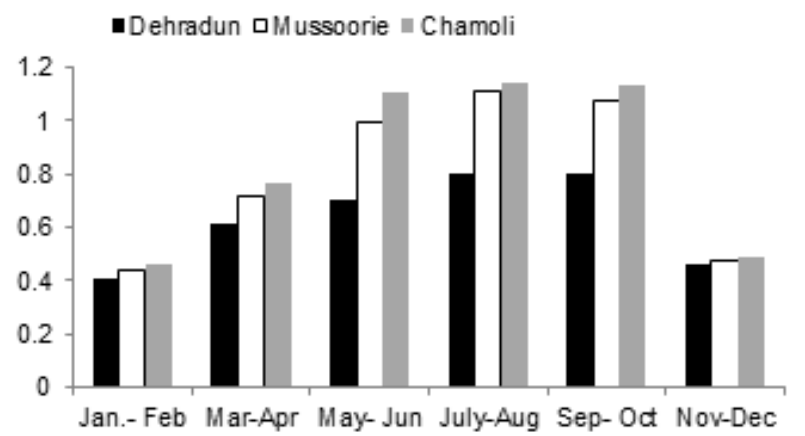

Fig. 1 Seasonal and altitudinal variation in solar terrestrial UV-B radiation $\mathrm{mw} / \mathrm{cm}^{2}$ in Uttarakhand Himalayan region India

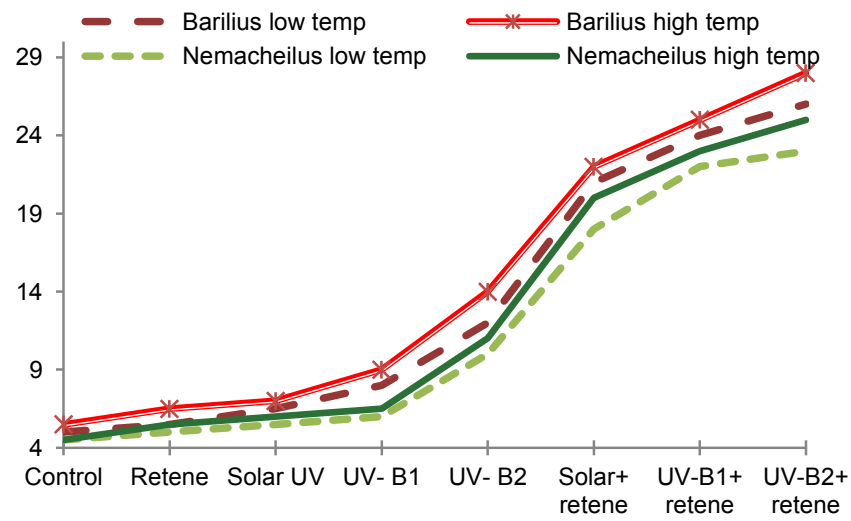

Fig. 2 Mortality rate at low and high temperature in fishes after UV radiation and retene.

The amount of UV-B reaching the surface of earth depends on the thickness of the ozone layer and atmosphere. This varies due to solar zenith. The angle of solar radiation changes with latitude, season, time of the day so that the highest effluence rate of UV-B radiation occurs in at the equatorial region in midsummer at mid day. However the relation ratio UVR to photosynthetically active radiation (PAR) is greatest during dawn and dusk. Phytoplankton compositions are affected by different environmental factors such as $\mathrm{pH}$, temperature, light and environmental pollutants [21]. UV-B also participates in indirect damage to macromolecules, provokes free radical production and induces a significant decrease in antioxidants [22]. Depletion of ozone layer and increase in UV radiation interact DNA, protein, chromophores and skin pigments in aquatic and terrestrial animals [23].

Barilius bendelisis commonly known as Indian Hill Trout is an upland water fish of south East Asia, plays significant role in the capture fishery in several parts of Himalayan region of Uttarakhand [24]. The harmful effects of the excess solar radiation on fish were recognized in fish and sunburn was reported in several species. UV radiation is able to scatters rapidly in water with biologically useful amounts to at least 50-m depth in clear aquatic environments. The distribution of fish larvae in the presence of UV radiation has been little studied although the UV radiation directed movements of the other planktonic organism have been well documented [25], [26]. Many of the UV-B induced biochemical and physiological changes are valid as biomarkers using aquatic species for detection of the degree of stress. Fish are susceptible to UV- B radiation with sensitivity varying within groups. Skin damage is the most commonly reported effect of solar UV-B on fish. UV- B induced changes have also been noted in fish inhabiting natural water. Eggs and larvae also have limited behavioral capabilities to avoid UV-B exposure due to their reduced mobility and some species cannot detect UV-B radiation in the early developmental stages [27]. Change in phototoxicity due to temperature is supported by the study [28]. Low temperatures inhibit immunological responsiveness in fishes but higher temperature may have either positive or negative effects on immune function. Fish fauna abundance, growth and development is affected by 
monsoon season, migratory behavior and changes in physicochemical nature of water temperature, dissolve oxygen, velocity, $\mathrm{pH}$, light and turbidity. Studies with numerous fish species have shown that UV-B radiation can be detrimental to fish especially at embryo and larval stages. The most severe effects of UV-B radiation impair larval development and decrease offspring recruitment [29]. Because fish are poikilotherms, ambient temperature has pervasive effects on their physiological function including immune function and growth. Temperature along with photoperiod cause seasonal change in the behavior and immune function of fish affecting both innate and acquired immune responses. Temperature affect migration movement and feeding pattern. Decrease in hatching rate in fish Pogrus major [30], lipid peroxidation in fish with anthracene were observed. Results on dose and intensity dependent changes in mortality rate in the fish were supported by studies on photohaemolysis [15], fish and Cyclops with photosensitizers [31], [32].

Retene is a natural chemical present in the plants. Aquatic animals are naturally exposed to retene due to its presence in water bodies. Fish larva exposed to artificial UV-B with retene show maximum mortality and lipid peroxidation indicating that enhanced solar UV-B exposure could be lethal to fish fauna. Artificial UV-B had a strong damaging effect than natural solar radiation and become highly toxic in presence of retene. Barilius bendelisis is more sensitive than Nemacheilus rupicola due to enhanced UV-B. Retene photoproducts generate reactive oxygen species leading to cell injury and mortality thus are threat to fish fauna and aquatic biodiversity. Solar terrestrial UV monitoring data are useful for future planning of weather, climate, human health and biodiversity conservation. Results indicate that climate change and enhanced ultraviolet radiation affect ecosystem and fish biodiversity.

\section{ACKNOWLEDGMENT}

Authors are thankful to University Grants Commission (UGC), New Delhi for providing financial assistance 43$562 / 2014$ (SR) and to the institution for providing necessary facility.

\section{REFERENCES}

[1] W. F. Vincent and C. Belzile (2002). In ultraviolet radiation and Arctic Ecosystem. Ecological studies, ed: Hessen D., Springer- Verlag, Berlin, Heidelberg. 153, 137.

https://doi.org/10.1007/978-3-642-56075-0_7

[2] A. R. Blaustein, L. K. Belden, A. C. Hatch, L. K. Kats, P. D. Hoffman, J. B. Hays, A. Marco, D. P. Chivers and J. M. Kiesecker (2001). In ecosystem, evolution and ultraviolet radiation eds.: C. S. Cockell and A. R. Blaustein, Springer-Verlag, New York. 63.

[3] J. Rozema, B. Van Geel, L. O. Bjorn, J. Lean and S. Madronich (2002). Towards solving the UV puzzle. Science. 296, 1621. https://doi.org/10.1126/science.1070024

[4] D. P. Hader, C. E. Williamson, S. Wangberg, A. Rautio, M. Rose, K. C., Gao, K., Helbling, E. W., Sinha, R. P., and Worrest, R. (2003). Effects of UV radiation on aquatic ecosystems and interactions with other environmental factors, Photochem. Photobio. S., 14, 108-126. https://doi.org/10.1039/C4PP90035A

[5] A. G. J. Buma, P. Boelen and W. H. Jeffery (2003). UVR induced DNA damage in aquatic organisms. In UV effects in aquatic organisms and ecosystem (eds Helbing E. R. and Zagaress H.) Royal Society of Chemistry. Combridge. UK 10, 291.

https://doi.org/10.1039/9781847552266-00291

[6] C. A. Castro - Perez (2004). Effects of ultraviolet radiation exposure on the swimming performance and hematological parameters of Tambaqui colossoma macropomum. International Congress on the Biology of Fish. Tropical Hotel Resort, Manaus Brazil, August. 1-5.

[7] G. C. Reisel, A. J. Miller, E. C. Weatherhead, L. E. Flynn, R. M. Nagatani, G. C. Tiao and D. J. Wuebbles (2005). Trend analysis of total ozone data for turnaround and dynamical contributions. $J$. Geophys. Res. 110, D16306.

https://doi.org/10.1029/2004JD004662

[8] R. L. McKenzie, P. J. Ancamp, A. F. Bais, L. O. Bjorn and M. Ilyas (2007). Changes on biologically- active ultraviolet radiation reaching the earth, s surface. Photochem. Photobiol. Sci. 6, 218. https://doi.org/10.1039/B700017K

[9] D. P. Arfsten, D. J. Schaeffer and D. C. Mulveny (2007). The effects of near Ultraviolet radiation on the effects of polycyclic aromatic hydrocarbon in animals and plants. A review, Ecotoxicol. Environ. Science. 33, 1.

https://doi.org/10.1006/eesa.1996.0001

[10] R. R. Bhandari and P. K. Sharma (2010). UV-B radiation and high light induced oxidative damage in Phormidium corium may cause bleaching to associated coral reefs. Ind. J. Geo-Mar. Sci.39, 423.

[11] J. Y. Lin and D. E. Fisher (2007). Melanocyte biology and skin pigmentation. Nature. 445,843 https://doi.org/10.1038/nature05660

[12] Y. Yamaguchi, J. Beer and V. Hearing (2008). Melanin mediated apoptosis of epidermal cells damaged by ultraviolet radiation: factor influencing the incidence of skin cancer. Arch. Dermatol. Res. 300, 43. https://doi.org/10.1007/s00403-007-0807-0

[13] R. L. McKeniezie, P. J. Aucamp, A. F. Bais, L. O. Bjorn, M. Ilyas and S. Madronich (2011). Ozone depletion and climate change: impacts on UV radiation. Photochem. Photobiol. Sci. 10, 182. https://doi.org/10.1007/s00403-007-0807-0

[14] C. E. Williamson, J. M. Fischer, S. M. Bollens, E. P. Overholt and J. K. Breckenridge (2011) Comprehensive theory of zooplankton diel vertical migration, integrating ultraviolet radiationand water transparency into the biotic paradigm. Limnol. Oceanogr.56, 16031623

https://doi.org/10.4319/lo.2011.56.5.1603

[15] S. Kumar, S. Devi, P. Misra and Priyanka (2009). Solar and artificial ultraviolet-B induced erythrocytes hemolysis with photosensitizers, Indian J. Exp. Biology., 47, 906

[16] C. Tisher and Songlake (2001). Culturing Daphnia in eight easy steps. Aquamam. 10 26-34.

[17] R. C. Smith and R. P. Anderson (1987). Methods for determination of lipid peroxidation in biological sample. Free. Rad Mad. 3, 341. https://doi.org/10.1016/S0891-5849(87)80044-8

[18] E. Beutler, O. Duron and B. M. Kelly (1963). Improved method for the determination of glutathione. J. Lab. Clin. Med. 61, 882.

[19] S. Takahara, H. B. Hamilton, J. V. Neat and T. V. Kabara (1960). Hypocatalasemic. A new genetic carrier state. J. Clin. Invest. 39, 610. https://doi.org/10.1172/JCI104075

[20] R.A. Fisher (1963) Statistical methods for research workers. Oliver and Boyd, London. $4^{\text {th }}$ ed. 14:119-193.

[21] F. Buzzi (2002). Phytoplankton assemblages in two sub-basins of Lake Como. J. Limnol., 61, 117- 128. https://doi.org/10.4081/jlimnol.2002.117

[22] I. Pattison David and M. Davies. (2006). Actions of Ultraviolet light on Cellular structures (Book). Cancer Cell structures. Carcinogens and Genomic Instability. 96, 131. https://doi.org/10.1007/3-7643-7378-4_6

[23] M. Laura, D. Gendron, R. J. Knell, E. A. O. Toole, M. Singh and A.W. Karina (2011). Acute sun damage and photoprotective response in whales, Proc. R. Soc., B 10, 1903.

[24] S. Sah, A. Barat, V. Pande, J. Sati and C. Goel (2011). Population structure of India Hill Trout (Barilius bedelisis) Inferred from variation in Mitochondrial Dua Sequence. Advan. Biol. Res. 5, 93. 
[25] S. Kumar and P. Kumari (2011). High intensity ultraviolet radiation induced changes in aquatic arthropod with retene and riboflavin. Environ. Con. J. 12, 83.

[26] J. Asta, B. Pal, D. Arne, A. E. Stefan, R. Jorg, M. Krsitin, F.H Michael, B.G. William, and M. Johan (2011). Solar radiation and human health, Rep. Prog. Phys., 74, 170.

[27] M.H. Olson, M.R. Colip, J.S. Geriach, D.L. Mitchell (2006). Quantifying ultraviolet radiation mortality risk in bluegill larvae: effects on nest location. Ecol. Appl. 16, 328. https://doi.org/10.1890/05-0287

[28] A.C. Cheng, Y.Y. Chen and J.C. Chen (2009). Effects of temperature change on the innate cellular and humeral immune responses of orange- spotted grouper Epinephelus coioides and its susceptibility to Vibrio alginolyticus. Fish Shellfish Immunol. 26, 768. https://doi.org/10.1016/j.fsi.2009.03.011

[29] H.I. Browman, C.A. Rodringuez, F. Beland, J.J. Cullen, R.P. Davis, J. H. M. Kouwenberg, P.S. Zuhn, B. MacArthur, J. H. Rung, St. Pierre and R.D. Vetter (2006). Impact of ultraviolet radiation on marine crustacean zooplankton and ichthyoplankton: a synthesis of results from the estuary and Gulf of St. Lawrence, Canada. Mar. Ecol. Prog. Ser. 199, 293. https://doi.org/10.3354/meps199293

[30] Y. Fukunishi, R. Masuda and Y. Yamashita (2010). Exposure of eggs to solar UV-B leads to reduced hatching rates in two sparid fishes, red sea bream Pagrus major and Black sea bream Acanthopagrus schlegeli. J. Fish. Biol. 76, 734. https://doi.org/10.1111/j.1095-8649.2009.02517.x

[31] S. Kumar, P. Kumari and P. Mishra (2011). Lipidperoxidation and mortality in fish larvae after solar ultraviolet radiation. $J$. Environmental Res. Dev. 5, 898.

[32] S. Kumar, S. Nagar and N. Chowdhary (2015). Effect of ultraviolet radiation and temperature change on zooplankton- Cladocera and Copepoda. Int. J. Pharmacol. Bio. Sci. 9(3), 1-7. 